\title{
Quantitation of tizoxanide in multiple matrices to support cell culture, animal and human research.
}

Megan Neary ${ }^{1,3}$, Usman Arshad ${ }^{1,3}$, Lee Tatham ${ }^{1,3}$, Henry Pertinez ${ }^{1,3}$, Helen Box ${ }^{1,3}$, Rajith KR Rajoli ${ }^{1,3}$, Anthony Valentijn ${ }^{1,3}$, Joanne Sharp ${ }^{1,3}$, Steve P Rannard ${ }^{2,3}$, Giancarlo A Biagini, ${ }^{4}$ Paul Curley ${ }^{1,3}$, Andrew Owen ${ }^{1,3}$.

${ }^{1}$ Department of Pharmacology and Therapeutics, University of Liverpool, Liverpool, L7 3NY, UK

${ }^{2}$ Department of Chemistry, University of Liverpool, Liverpool, L69 3BX, UK

${ }^{3}$ Centre of Excellence in Long-acting Therapeutics (CELT), University of Liverpool, Liverpool, L7 3NY, UK

${ }^{4}$ Centre for Drugs and Diagnostics, Liverpool School of Tropical Medicine, Liverpool L3 5QA, UK.

\author{
Author for correspondence: \\ Dr Paul Curley \\ Department of Pharmacology and Therapeutics \\ Centre of Excellence in Long-acting Therapeutics (CELT) \\ University of Liverpool \\ United Kingdom \\ Tel: +44 (0) 1517958560 \\ E-mail: pcurley@liverpool.ac.uk
}

Key words: Tizoxanide, LC-MS/MS, plasma, SARS-CoV-2, COVID-19

\section{Conflicts of interest statement}

$A O$ and $S R$ have received research funding from AstraZeneca and ViiV and consultancies from Gilead; $A O$ has additionally received funding from Merck and Janssen and consultancies from ViiV and Merck not related to the current paper. No other conflicts are declared by the authors.

\section{Funding}

This work was funded by UKRI using funding repositioned from EP/R024804/1 as part of the UK emergency response to COVID-19. The authors also acknowledge research funding from EPSRC 
(EP/S012265/1), NIH (R01Al134091; R24Al118397), European Commission (761104) and Unitaid (project LONGEVITY).

\begin{abstract}
Currently nitazoxanide is being assessed as a candidate therapeutic for SARS-CoV-2. Unlike many other candidates being investigated, tizoxanide (the active metabolite of nitazoxanide) plasma concentrations achieve antiviral levels after administration of the approved dose, although higher doses are expected to be needed to maintain these concentrations across the dosing interval in the majority of patients. Here an LC-MS/MS assay is described that has been validated in accordance with Food and Drug Administration (FDA) guidelines. Fundamental parameters have been evaluated, and these included accuracy, precision and sensitivity. The assay was validated for human plasma, mouse plasma and Dulbeccos Modified Eagles Medium (DMEM) containing varying concentrations of Foetal Bovine Serum (FBS). Matrix effects are a well-documented source of concern for chromatographic analysis, with the potential to impact various stages of the analytical process, including suppression or enhancement of ionisation. Therefore, a robustly validated LC-MS/MS analytical method is presented capable of quantifying tizoxanide in multiple matrices with minimal impact of matrix effects. The validated assay presented here was linear from $15.6 \mathrm{ng} / \mathrm{mL}$ to $1000 \mathrm{ng} / \mathrm{mL}$. Accuracy and precision ranged between $102.2 \%$ and $113.5 \%, 100.1 \%$ and $105.4 \%$, respectively. The presented assay here has applications in both pre-clinical and clinical research and may be used to facilitate further investigations into the application of nitazoxanide against SARS-CoV-2.
\end{abstract}

\title{
Introduction
}

Nitazoxanide (NTZ) is a thiazolide anti-protozoal drug, approved to treat diarrhoea caused by the parasites Cryptosporidium and Giardia in children and adults [1, 2], and is administered orally as a suspension or tablet twice daily with food [2]. Additional efficacy has been demonstrated both in vitro and in vivo against a wide range of parasites, bacteria, fungi and viruses [3-9]. This broad-spectrum of activity is in part attributed to NTZs rapid transformation into its deacetylated active metabolite tizoxanide (TIZ) [4]. NTZ has previously been considered for drug repurposing to treat respiratory viral infections [9], including Middle Eastern respiratory syndrome (MERS) [10], with clinical trials having assessed its suitability to treat acute influenza [11, 12]. 
Currently NTZ is being assessed as a candidate therapeutic for severe acute respiratory syndrome coronavirus 2 (SARS-CoV-2), with 25 trials listed on clinicaltrials.gov [13]. In vitro evaluation of the activity of NTZ against SARS-CoV-2 in Vero E6 cells generated an $\mathrm{EC}_{90}$ estimated at $4.65 \mu \mathrm{M}[14,15]$. Subsequently, TIZ was additionally confirmed to have antiviral activity with an $\mathrm{EC}_{90} 3.16 \mu \mathrm{M}$ under similar assay conditions [16]. Unlike many other candidates being investigated, TIZ plasma concentration achieve antiviral levels after administration of the approved dose [14],although higher doses are expected to be needed to maintain these concentrations across the dosing interval in the majority of patients [17]. Several mechanisms of action for NTZ against SARS-CoV-2 have been proposed and are summarised by Lokhande et al. [18].NTZ has previously been demonstrated to inhibit production of pro-inflammatory cytokines and interleukin-6 in peripheral blood mononuclear cells in vitro [19], and reduce interleukin-6 plasma levels in mice [20]. It has been hypothesised that this may assist host anti-inflammatory responses during SARS-CoV-2 disease progression and thus lessen the SARS-CoV-2 cytokine storm $[9,18]$.

Research into the suitability of NTZ as a treatment for SARS-CoV-2 is currently ongoing and includes dose optimisation, tolerability and drug-interaction studies [17, 21]. One uncertainty relating to the putative utility of NTZ is that TIZ is highly protein bound in plasma of humans [22]. However, whether this binding is high affinity / low capacity or low affinity / high capacity is currently unknown and could have a profound impact upon the probability of success $[23,24]$. Methods for quantification of concentrations of NTZ and TIZ in a variety of matrices are required to better understand the exposureresponse relationship, in vitro, in vivo and in humans. Currently few validated liquid chromatography tandem mass spectrometry (LC-MS/MS) assays are available to quantify NTZ and TIZ in relevant biological matrices. Previous studies include a validated LC-MS method for quantifying NTZ and TIZ in mouse plasma, lung, BAL cells, liver, spleen kidney and heart with a limit of quantification (LOQ) of 0.97 $\mathrm{ng} / \mathrm{mL}$ [25]. As well as a LC-MS/MS methods validated in goat faeces with a limit of detection of 5ng/g [26]. A high performance liquid chromatography (HPLC) method has been validated for NTZ and TIZ in plasma but is anticipated to lack the sensitivity needed to determine the pharmacokinetics of NTZ and TIZ as a SARS-CoV-2 treatment [27].

Here an LC-MS/MS assay is described that has been validated in accordance with Food and Drug Administration (FDA) guidelines [28]. Fundamental parameters have been evaluated, and these included accuracy, precision and sensitivity. Other validation criteria also included linearity, recovery, reproducibility and stability of TIZ within selected matrices. The assay was validated for human plasma, 
bioRxiv preprint doi: https://doi.org/10.1101/2021.05.27.445500; this version posted May 28, 2021. The copyright holder for this preprint (which

was not certified by peer review) is the author/funder, who has granted bioRxiv a license to display the preprint in perpetuity. It is made available under aCC-BY-NC-ND 4.0 International license.

mouse plasma and Dulbeccos Modified Eagles Medium (DMEM) containing varying concentrations of Foetal Bovine Serum (FBS). Matrix effects are a well-documented source of concern for chromatographic analysis, with the potential to impact various stages of the analytical process [29], including suppression or enhancement of ionisation [28]. Therefore, a robustly validated LC-MS/MS analytical method is presented capable of quantifying TIZ in multiple matrices with minimal impact of matrix effects. 


\section{Methods and Materials}

\section{Materials}

TIZ and the internal standard (IS) TIZ-D4 were purchased from Toronto Research Chemicals inc (Toronto, Canada). Drug free mouse plasma and human plasma with lithium heparin were purchased from VWR International (PA, USA). LCMS grade acetonitrile (ACN) was purchased from Fisher Scientific (MA, USA). All other consumables were purchased from Merck Life Science UK LTD (Gillingham, UK) and were of LCMS grade.

\section{Tuning for Tizoxanide and Internal Standard}

A stock solution of $1 \mathrm{mg} / \mathrm{mL}$ of TIZ or TIZ-D4 was prepared in ACN. From this stock a solution of $10 \mathrm{ng} / \mathrm{mL}$ was prepared in H2O:methanol (50:50) for tuning. Detection was performed using a SCIEX 6500+ Qtrap (SCIEX MA,USA) operating in negative mode. TIZ or TIZ-D4 was infused at $10 \mu \mathrm{L} / \mathrm{min}$ in order to optimise compound-specific parameters (declustering potential, collision energy and collision exit potential) and source specific parameters (curtain gas, ionisation voltage, temperature, nebuliser gas and auxiliary gas).

\section{Chromatographic Separation}

TIZ was resolved using a kinetex C18 column $(2.7 \mu \mathrm{M}, 2.1 \times 100 \mathrm{~mm}$ Phenomenex CA, USA) using a $5 \mu \mathrm{L}$ injection. The following multistep gradient was used with $\mathrm{H}_{2} \mathrm{O}+0.1 \%$ formic acid (mobile phase A) and $\mathrm{ACN}+0.1 \%$ formic acid (mobile phase $\mathrm{B}$ ) at a flow rate of $0.4 \mathrm{~mL} / \mathrm{min}$ : the initial conditions were $5 \% \mathrm{~A}$ and $95 \%$ B and held for 1 minute. Mobile phase B was rapidly increased to $80 \%$ over 0.5 mins. The gradient was then slowly increased to $95 \%$ B till 4 mins. This was held for 0.5 mins when the initial conditions were returned and held for 0.5 mins.

\section{Extraction from mouse plasma, human plasma and foetal bovine serum}

The assay described here was developed to quantify TIZ from in vitro (DMEM plus 50\%, 25\%, 12\%, 10\%, $5 \%$ and $2 \% \mathrm{FBS}$ or $50 \%$ and $10 \%$ human plasma) and in vivo (mouse plasma and human plasma) matrices to support SARS-CoV-2 preclinical research. $100 \mu \mathrm{L}$ of standard quality control (QC) sample or untreated matrix was pipetted into $7 \mathrm{~mL}$ glass tubes. $500 \mu \mathrm{L}$ of ACN containing IS (20ng/mL) was added to each tube and thoroughly vortexed. Following vortexing, the samples were centrifuged at $3500 \mathrm{rpm}$ for $5 \mathrm{mins}$ at $4^{\circ} \mathrm{C}$. $500 \mu \mathrm{L}$ of supernatant was then transferred to fresh $7 \mathrm{~mL}$ tubes and the samples were evaporated to dryness under a gentle stream of nitrogen. All samples were reconstituted in $100 \mu \mathrm{L}$ of reconstitution 
buffer $\left(30 \% \mathrm{H}_{2} \mathrm{O}, 49 \% \mathrm{ACN}\right.$ and $\left.21 \% \mathrm{DMF}\right) .50 \mu \mathrm{L}$ was the transferred to chromatography vials and analysed.

\section{Linearity}

Calibrators were prepared by spiking untreated matrix with TIZ followed by serial dilution, ranging from $15.6 \mathrm{ng} / \mathrm{mL}$ to $1000 \mathrm{ng} / \mathrm{mL}$. Linearity was assessed over 3 independent runs. Acceptance criteria were as follows; deviation of interpolated standards from stated concentrations were set at $15 \%$, excluding the lower limit of quantification (LLOQ) where deviation was set at no more than $20 \%$. Acceptable $\mathrm{R}^{2}$ was set at $>0.99$.

\section{Recovery}

Recovery was assessed at 3 concentrations $(40 \mathrm{ng} / \mathrm{mL}, 400 \mathrm{ng} / \mathrm{mL}$ and $800 \mathrm{ng} / \mathrm{mL}$ ) covering the dynamic range of the assay. The peak area of extracted samples was compared to extracted blank matrix spiked with the expected concentrations.

\section{Matrix Effects}

Matrix effect was determined by comparing the signal produced by an extracted blank to the peak produced by the lower limit of quantification (LLOQ). FDA guidelines require the signal of endogenous interference be no more than $20 \%$ of the LLOQ.

\section{Accuracy and Precision}

Accuracy and precision were determined for intra- and inter-assay variability. The degree of variation was calculated by determining the $\%$ of the interpolated concentration of QCs to the expected concentration. Accuracy (\% variability of accuracy $=$ interpolated value/expected value*100) and precision (\%variation of precision $=$ standard deviation $/$ mean value*100) were determined at 3 concentrations $(40 \mathrm{ng} / \mathrm{mL}, 400 \mathrm{ng} / \mathrm{mL}$ and $800 \mathrm{ng} / \mathrm{mL}$ ) in triplicate. Acceptable variation for accuracy and precision was set at $15 \%$ and at $20 \%$ for the lower concentrations. 


\section{Results}

\section{Recovery of Tizoxanide}

TIZ and IS were detected using the optimised analyte specific and global parameters found in table 1. The mean recovery was $57.7 \% \pm 7.93$ and $51.8 \% \pm 9.50$ for mouse plasma and human plasma, respectively. Recovery from DMEM with varying percentages of serum was $45.2 \% \pm 3.84$ (50\% FBS), $48.1 \% \pm 4.72$ (25\% FBS), $50.3 \% \pm 6.54$ (12\% FBS), $50.1 \% \pm 0.63$ (10\% FBS), $42.1 \% \pm 4.20$ (5\% FBS), $42.8 \%$ \pm 4.50 ( $2 \% \mathrm{FBS}$ ), $50.5 \% \pm 9.80$ (0\% FBS), $51.0 \% \pm 2.30$ ( $50 \%$ human plasma) and $40.5 \% \pm 4.68$ ( $10 \%$ human plasma). While recovery varied between each matrix, mean recovery within each matrix demonstrated high reproducibility (example recoveries are shown in Figure 1).

\section{Linearity}

Extracted calibrators demonstrated strong linearity (mouse plasma $R^{2}=0.9997$, human plasma $R^{2}=$ $0.9991,50 \%$ human plasma $R^{2}=0.9983,10 \%$ human plasma $R^{2}=0.9992,50 \%$ FBS $R^{2}=0.9970,25 \% \mathrm{FBS}$ $R^{2}=0.9992,12 \% F B S R^{2}=0.9996,10 \% F B S R^{2}=0.9992,5 \% F B S R^{2}=0.9995$ and $\left.2 \% F B S R^{2}=0.9995\right)$ meeting all acceptance criteria (Figure 2). The calibration curve was fit to the data using a linear equation with sample weighting of $1 / X$.

\section{Selectivity}

Interference from endogenous compounds of a matrix is a well-documented confounding effect in bioanalysis. The Peak area produced by the LLOQ was compared to detectable signal at the retention time of TIZ (2.46 mins) and expressed as a percentage of the peak area of the LLOQ (Table 2). Representative chromatograms are shown in figure 3. Matrix effect was not deemed to interfere with the assay as endogenous signal fell below $7 \%$ in all matrices.

\section{Accuracy and Precision}

The assay described here was fully validated using mouse plasma. The variation in accuracy and precision was determined within each assay (inter-assay) and across 3 replicates of the assay (intraassay). Variance in accuracy and precision was determined by comparing the interpolated values of extracted QCS to the known values. Inter assay fell below 15\% for accuracy (range $-13.5 \%-2.2 \%$ ) and precision (range $0.9 \%-5.4 \%$ ) at all concentrations across each replicate run. Mean intra assay variance in accuracy and precision was $-3.1 \%$ and $3.6 \%$ respectively. FDA guidelines require part validation for minor changes to the assay (e.g., change of matrix). The remaining matrices were assessed for inter 
bioRxiv preprint doi: https://doi.org/10.1101/2021.05.27.445500; this version posted May 28, 2021. The copyright holder for this preprint (which

was not certified by peer review) is the author/funder, who has granted bioRxiv a license to display the preprint in perpetuity. It is made available under aCC-BY-NC-ND 4.0 International license.

assay variation [28]. The intra-assay \% error in accuracy was below $15 \%$ at all levels in human plasma (range -3.3 - 8.0) and FBS (range -1.4-10.8). Intra-assay error of precision also fell below $15 \%$ in human plasma (range 1.8 - 7.0) and FBS (range 1.1-7.0, Table 3). 


\section{Discussion}

The anti-SARS-CoV-2 activity of NTZ is being investigated in vitro, in vivo, and in clinical trials. Unlike many candidates being explored for direct repurposing as SARS-CoV-2 antivirals, the pharmacokinetics of NTZ do suggest that antiviral concentrations can be achieved in humans when benchmarked against targets derived from in vitro studies. However, uncertainty about high protein binding of TIZ in plasma, the specific mechanism of action, and the appropriate dose necessitates a careful understanding of the exposure-response relationship. A recent multicenter, randomised, double-blind, placebo-controlled trial, in adult patients presenting up to 3 days after onset of symptoms and with PCR-confirmed SARSCoV-2 infections indicated some antiviral activity at 500mg three times a day [30]. However, much more data are required to support the candidacy of NTZ (including at higher doses), and studies should incorporate an understanding of the pharmacokinetics during SARS-CoV-2 infection.

A greater understanding of the pharmacokinetic-pharmacodynamic relationship requires robust, validated LC-MS/MS methods with utility in relevant biological matrices. The selection of matrices within this study included human and mouse plasma and DMEM plus $50 \%-2 \%$ FBS or $50 \%-10 \%$ human plasma. These were chosen for their relevance to clinical, in vitro and in vivo investigations of NTZ as a SARSCoV-2 therapeutic. Although human and mouse plasma have some homogeneity, species differences can lead to changes in assay behaviour. As demonstrated by protein binding being commonly lower in preclinical species than humans [31]. Furthermore, differences in in vitro methods can often result in differential percentages of FBS being used to supplement DMEM in different studies. Given that previously outlined matrix effects have the potential to impact assay performance, and that this problem could be further compounded by the high protein binding observed for $\mathrm{TIZ},>99.9 \%$ in plasma [2], a thorough investigation of matrix effect was warranted. Small differences in recovery of TIZ within different matrices were evident, but all recovery percentages were seen to be reproducible for each of the matrices (deviation <15\%). Furthermore, the endogenous signal from each of the matrices was seen to be less than $7 \%$ of the LLOQ, falling well within the $20 \%$ acceptance criteria set out in FDA guidance [28]. Thus, this matrix effect is unlikely to meaningfully impact assay performance.

The decision to focus on TIZ exclusively was driven by the observation that NTZ is rapidly converted to TIZ, and that previous studies have not detected NTZ in plasma, the main matrix of interest [32]. The assay was able to quantify $\mathrm{TIZ}$ within multiple matrices, generating highly reproducible, precise and accurate results, indicating a tolerance to the negative impact of matrix effects. The described assay will be further developed to include the major metabolite of TIZ, tizoxanide glucuronide. In summary, a 
bioRxiv preprint doi: https://doi.org/10.1101/2021.05.27.445500; this version posted May 28, 2021. The copyright holder for this preprint (which

was not certified by peer review) is the author/funder, who has granted bioRxiv a license to display the preprint in perpetuity. It is made available under aCC-BY-NC-ND 4.0 International license.

highly sensitive TIZ LC-MS/MS assay is presented, which fully meets FDA bioanalytical method development guidelines. 


\section{References}

1. Anderson, V.R. and M.P. Curran, Nitazoxanide. Drugs, 2007. 67(13): p. 1947-1967.

2. FDA. ALINIA Nitazoxanide drug label highlights of prescribing information. Reference ID: 3956992 2002; Available from:

https://www.accessdata.fda.gov/drugsatfda docs/label/2016/021497s001,021498s004lbl.pdf.

3. Broekhuysen, J., et al., Nitazoxanide: pharmacokinetics and metabolism in man. International journal of clinical pharmacology and therapeutics, 2000. 38(8): p. 387-394.

4. Esposito, M., et al., Induction of tachyzoite egress from cells infected with the protozoan Neospora caninum by nitro-and bromo-thiazolides, a class of broad-spectrum anti-parasitic drugs. International journal for parasitology, 2007. 37(10): p. 1143-1152.

5. Ortiz, J.J., et al., Comparative clinical studies of nitazoxanide, albendazole and praziquantel in the treatment of ascariasis, trichuriasis and hymenolepiasis in children from Peru. Transactions of the Royal Society of Tropical Medicine and Hygiene, 2002. 96(2): p. 193-196.

6. Dubreuil, L., et al., In vitro evaluation of activities of nitazoxanide and tizoxanide against anaerobes and aerobic organisms. Antimicrobial agents and chemotherapy, 1996. 40(10): p. 2266-2270.

7. Rossignol, J.-F., et al., Effect of nitazoxanide for treatment of severe rotavirus diarrhoea: randomised double-blind placebo-controlled trial. The Lancet, 2006. 368(9530): p. 124-129.

8. Korba, B.E., et al., Nitazoxanide, tizoxanide and other thiazolides are potent inhibitors of hepatitis $B$ virus and hepatitis $C$ virus replication. Antiviral research, 2008. 77(1): p. 56-63.

9. Mahmoud, D.B., Z. Shitu, and A. Mostafa, Drug repurposing of nitazoxanide: can it be an effective therapy for COVID-19? Journal of Genetic Engineering and Biotechnology, 2020. 18(1): p. 1-10.

10. Rossignol, J.-F., Nitazoxanide, a new drug candidate for the treatment of Middle East respiratory syndrome coronavirus. Journal of infection and public health, 2016. 9(3): p. 227-230.

11. Haffizulla, J., et al., Effect of nitazoxanide in adults and adolescents with acute uncomplicated influenza: a double-blind, randomised, placebo-controlled, phase $2 b / 3$ trial. The Lancet Infectious diseases, 2014. 14(7): p. 609-618.

12. Gamiño-Arroyo, A.E., et al., Efficacy and safety of nitazoxanide in addition to standard of care for the treatment of severe acute respiratory illness. Clinical Infectious Diseases, 2019. 69(11): p. 1903-1911.

13. ClinicalTrials.gov. ClinicalTrials.gov. Clinical Trials. 2021 SARS-CoV-2 nitazoxanide clincal trials search. 2021; Available from: https://clinicaltrials.gov/ct2/results?cond=sars-cov2\&term $=$ nitazoxanide \&cntry $=\&$ state $=\&$ city $=\&$ dist $=$.

14. Arshad, U., et al., Prioritisation of potential anti-SARS-CoV-2 drug repurposing opportunities based on ability to achieve adequate target site concentrations derived from their established human pharmacokinetics. medRxiv, 2020.

15. Wang, M., et al., Remdesivir and chloroquine effectively inhibit the recently emerged novel coronavirus (2019-nCoV) in vitro. Cell research, 2020. 30(3): p. 269-271.

16. Stachulski, A.V., et al., Therapeutic Potential of Nitazoxanide: An Appropriate Choice for Repurposing versus SARS-CoV-2? ACS infectious diseases, 2020.

17. Rajoli, R.K., et al., Dose prediction for repurposing nitazoxanide in SARS-CoV-2 treatment or chemoprophylaxis. British Journal of Clinical Pharmacology, 2020.

18. Lokhande, A.S. and P.V. Devarajan, A review on possible mechanistic insights of Nitazoxanide for repurposing in COVID-19. European Journal of Pharmacology, 2020: p. 173748.

19. Clerici, M., et al., The anti-infective Nitazoxanide shows strong immumodulating effects (155.21). 2011, Am Assoc Immnol. 
20. Hong, S.K., et al., Nitazoxanide suppresses IL-6 production in LPS-stimulated mouse macrophages and TG-injected mice. International immunopharmacology, 2012. 13(1): p. 23-27.

21. Pepperrell, T., et al., Review of safety and minimum pricing of nitazoxanide for potential treatment of COVID-19. Journal of virus eradication, 2020. 6(2): p. 52-60.

22. Zhao, Z., et al., The pharmacokinetics of nitazoxanide active metabolite (tizoxanide) in goats and its protein binding ability in vitro. J Vet Pharmacol Ther, 2010. 33(2): p. 147-53.

23. Boffito, M., et al., Toward Consensus on Correct Interpretation of Protein Binding in Plasma and Other Biological Matrices for COVID-19 Therapeutic Development. Clin Pharmacol Ther, 2020.

24. Maurer, T.S., Nonspecific binding considerations in the rational design and development of small molecule COVID-19 therapeutics. Clin Pharmacol Ther, 2021.

25. Gupta, A., et al., Pharmacokinetics, Metabolism, and Partial Biodistribution of "Pincer Therapeutic" Nitazoxanide in Mice following Pulmonary Delivery of Inhalable Particles. Molecular pharmaceutics, 2017. 14(4): p. 1204-1211.

26. Zhao, Z., et al., Metabolic profile of nitazoxanide in goat feces. Chromatographia, 2008. 68(9): p. 731-738.

27. Ruiz-Olmedo, M., et al., Sensitive high performance liquid chromatographic assay for nitazoxanide metabolite in plasma. Die Pharmazie-An International Journal of Pharmaceutical Sciences, 2009. 64(7): p. 419-422.

28. Administration, U.S.D.o.H.a.H.S.F.a.D., Bioanalytical Method Validation Guidance for Industry, U.S.D.o.H.a.H.S.F.a.D.A.C.f.D.E.a.R.C.C.f.V.M. (CVM), Editor. 2018. p. 44.

29. Hewavitharana, A.K., S.K. Tan, and P.N. Shaw, Strategies for the Detection and Elimination of Matrix Effects in Quantitative LC-MS Analysis. LC Gc North America, 2014. 32(1): p. 54-+.

30. Rocco, P.R.M., et al., Early use of nitazoxanide in mild Covid-19 disease: randomised, placebocontrolled trial. European Respiratory Journal, 2020.

31. Colclough, N., et al., Species differences in drug plasma protein binding. MedChemComm, 2014. 5(7): p. 963-967.

32. Mullokandov, E., et al., Protein binding drug-drug interaction between warfarin and tizoxanide in human plasma. 2014. 


\section{Tables}

Table 1 shows the optimised parameters used to detect TIZ and TIZ-D4 (IS).

\begin{tabular}{|c|c|c|c|c|c|c|}
\hline Parent $(\mathrm{m} / \mathrm{z})$ & $\begin{array}{l}\text { Product } \\
(\mathrm{m} / \mathrm{z})\end{array}$ & RT (Min) & DP (Volts) & EP (Volts) & $\begin{array}{c}\text { CE } \\
\text { (Volts) }\end{array}$ & $\begin{array}{c}\text { CXP } \\
\text { (Volts) }\end{array}$ \\
\hline Tizoxanide & $* 216.8$ & 2.45 & -160 & -10 & -18 & -23 \\
\hline 263.9 & $* * 113.9$ & 2.45 & -160 & -10 & -28 & -11 \\
\hline \multicolumn{6}{|l|}{ Tizoxanide-D4 } & -19 \\
\hline \multicolumn{7}{|l|}{267.9} \\
\hline \multirow{2}{*}{$\begin{array}{c}\text { Global } \\
\text { Parameters }\end{array}$} & Curtain Gas & $\begin{array}{c}\text { Collision } \\
\text { Gas }\end{array}$ & $\begin{array}{c}\text { Voltage } \\
\text { (V) }\end{array}$ & $\begin{array}{c}\text { Temperature } \\
\left({ }^{\circ} \mathrm{C}\right) \\
\end{array}$ & Gas 1 & Gas 2 \\
\hline & 50 & Medium & -4500 & 450 & 50 & 50 \\
\hline
\end{tabular}


Table 2 shows the endogenous signal from an extracted blank compared to the LLOQ of TIZ and the \% of the LLOQ. FDA guidelines require the signal produced by an extracted blank be no more than $20 \%$ of the LLOQ.

\begin{tabular}{cccc}
\hline Matrix & Blank Signal & LLOQ Peak Area & \% of LLOQ \\
\hline Mouse plasma & 221 & 29787 & 0.74 \\
\hline Human plasma & 1291 & 88711 & 1.45 \\
\hline $\mathbf{5 0 \% ~ H u m a n ~ p l a s m a ~}$ & 3134 & 99576 & 3.15 \\
\hline $\mathbf{1 0 \%}$ Human plasma & 3071 & 75860 & 4.10 \\
\hline $\mathbf{5 0 \%}$ FBS & 1697 & 57432 & 3.00 \\
\hline $\mathbf{2 5 \%}$ FBS & 2683 & 58665 & 4.60 \\
\hline $\mathbf{1 2} \%$ FBS & 2287 & 62582 & 3.70 \\
\hline $\mathbf{1 0} \%$ FBS & 1641 & 85409 & 1.92 \\
\hline $\mathbf{5 \%}$ FBS & 4869 & 102427 & 4.75 \\
\hline $\mathbf{2 \%}$ FBS & 6571 & 100366 & 6.55 \\
\hline
\end{tabular}


Table 3 shows the validation of TIZ extracted from mouse plasma. The data shows the average quantitated sample at 3 levels, the \% deviation in accuracy and the \% deviation in precision. Acceptance criteria is variation no more than $15 \%$, excluding the lower concentration where deviation may be no more than $20 \%$.

\begin{tabular}{|c|c|c|c|c|c|c|c|}
\hline & & \multicolumn{4}{|c|}{ Intra-day } & \multicolumn{2}{|c|}{ Inter-day } \\
\hline & & $\begin{array}{c}\text { Average } \pm \text { SD } \\
(\mathrm{ng} / \mathrm{mL})\end{array}$ & $\begin{array}{l}\text { Variance of } \\
\text { accuracy (\%) }\end{array}$ & $\begin{array}{c}\text { Variance of } \\
\text { precision (\%) }\end{array}$ & $\begin{array}{c}\text { Average } \pm \text { SD } \\
(\mathrm{ng} / \mathrm{mL})\end{array}$ & $\begin{array}{l}\text { Variance of } \\
\text { accuracy (\%) }\end{array}$ & $\begin{array}{l}\text { Variance of } \\
\text { precision (\%) }\end{array}$ \\
\hline \multirow{3}{*}{ Assay 1} & $40 \mathrm{ng} / \mathrm{mL}$ & $38.5 \pm 1.22$ & -3.8 & 3.2 & $37.0 \pm 2.14$ & -7.4 & 5.8 \\
\hline & $400 \mathrm{ng} / \mathrm{mL}$ & $408.8 \pm 7.81$ & 2.2 & 1.9 & $397.9 \pm 9.72$ & -0.5 & 2.4 \\
\hline & $800 \mathrm{ng} / \mathrm{mL}$ & $798.7 \pm 13.9$ & -0.2 & 1.7 & $789.5 \pm 19.36$ & -1.3 & 2.5 \\
\hline \multirow{3}{*}{ Assay 2} & $40 \mathrm{ng} / \mathrm{mL}$ & $34.6 \pm 1.87$ & -13.5 & 5.4 & & & \\
\hline & $400 \mathrm{ng} / \mathrm{mL}$ & $390.0 \pm 11.29$ & -2.5 & 2.9 & & & \\
\hline & $800 \mathrm{ng} / \mathrm{mL}$ & $767.3 \pm 38.88$ & -4.1 & 5.1 & & & \\
\hline \multirow{3}{*}{ Assay 3} & $40 \mathrm{ng} / \mathrm{mL}$ & $38.1 \pm 0.33$ & -4.9 & 0.9 & & & \\
\hline & $400 \mathrm{ng} / \mathrm{mL}$ & $395.0 \pm 6.23$ & 1.6 & 1.6 & & & \\
\hline & $800 \mathrm{ng} / \mathrm{mL}$ & $802.6 \pm 20.40$ & 0.3 & 2.5 & & & \\
\hline
\end{tabular}


Table 4 shows the part validation of each of the investigated matrices. The data shows the average quantitated sample at 3 levels, the \% deviation in accuracy and the \% deviation in precision. Acceptance criteria is variation no more than $15 \%$, excluding the lower concentration where deviation may be no more than $20 \%$.

\begin{tabular}{|c|c|c|c|c|}
\hline & & & \multicolumn{2}{|c|}{ Intra-day } \\
\hline & & $\begin{array}{c}\text { Average } \pm \text { SD } \\
(\mathrm{ng} / \mathrm{mL})\end{array}$ & $\begin{array}{c}\text { Variance of } \\
\text { accuracy (\%) }\end{array}$ & $\begin{array}{c}\text { Variance of } \\
\text { precision (\%) }\end{array}$ \\
\hline \multirow{3}{*}{ Human Plasma } & $40 \mathrm{ng} / \mathrm{mL}$ & $40.4 \pm$ & 1.0 & 2.6 \\
\hline & $400 \mathrm{ng} / \mathrm{mL}$ & $394.2 \pm$ & -1.4 & 7.0 \\
\hline & $800 \mathrm{ng} / \mathrm{mL}$ & $840.3 \pm$ & 5.0 & 4.4 \\
\hline \multirow{3}{*}{ Human Plasma $50 \%$} & $40 \mathrm{ng} / \mathrm{mL}$ & $40.2 \pm 1.02$ & 0.6 & 2.5 \\
\hline & $400 \mathrm{ng} / \mathrm{mL}$ & $387.0 \pm 10.87$ & -3.3 & 2.8 \\
\hline & $800 \mathrm{ng} / \mathrm{mL}$ & $784.6 \pm 16.78$ & -1.9 & 2.1 \\
\hline $40 \mathrm{ng} / \mathrm{mL}$ & $43.2 \pm 0.78$ & 8.0 & 1.8 & \\
\hline $400 \mathrm{ng} / \mathrm{mL}$ & $403.1 \pm 8.51$ & 0.8 & 2.1 & \\
\hline $800 \mathrm{ng} / \mathrm{mL}$ & $840.8 \pm 15.95$ & 5.1 & 1.9 & \\
\hline $40 \mathrm{ng} / \mathrm{mL}$ & $40.0 \pm 1.72$ & -0.1 & 4.3 & \\
\hline $400 \mathrm{ng} / \mathrm{mL}$ & $405.7 \pm 9.86$ & 1.4 & 2.4 & \\
\hline $800 \mathrm{ng} / \mathrm{mL}$ & $833.1 \pm 15.28$ & 4.1 & 1.8 & \\
\hline $40 \mathrm{ng} / \mathrm{mL}$ & $40.8 \pm 0.55$ & 2.1 & 1.4 & \\
\hline $400 \mathrm{ng} / \mathrm{mL}$ & $400.8 \pm 8.35$ & 0.2 & 2.1 & \\
\hline $800 \mathrm{ng} / \mathrm{mL}$ & $788.9 \pm 34.32$ & -1.4 & 4.4 & \\
\hline
\end{tabular}




\begin{tabular}{lcccc}
\hline & $40 \mathrm{ng} / \mathrm{mL}$ & $40.4 \pm 1.12$ & 1.1 & 2.8 \\
FBS 12\% & $400 \mathrm{ng} / \mathrm{mL}$ & $407.5 \pm 14.52$ & 1.9 & 3.6 \\
& $800 \mathrm{ng} / \mathrm{mL}$ & $831.3 \pm 14.10$ & 3.9 & 1.7 \\
\hline \multirow{2}{*}{ FBS 10\% } & $40 \mathrm{ng} / \mathrm{mL}$ & $40.4 \pm 1.04$ & 1.0 & 2.6 \\
& $400 \mathrm{ng} / \mathrm{mL}$ & $394.2 \pm 27.70$ & -1.4 & 7.0 \\
& $800 \mathrm{ng} / \mathrm{mL}$ & $840.3 \pm 36.74$ & 5.0 & 4.4 \\
\hline \multirow{2}{*}{ FBS 5\% } & $40 \mathrm{ng} / \mathrm{mL}$ & $41.4 \pm 0.47$ & 3.4 & 1.1 \\
& $400 \mathrm{ng} / \mathrm{mL}$ & $413.6 \pm 22.76$ & 3.4 & 5.5 \\
& $800 \mathrm{ng} / \mathrm{mL}$ & $846.3 \pm 36.53$ & 5.8 & 4.3 \\
\hline & $40 \mathrm{ng} / \mathrm{mL}$ & $42.5 \pm 1.01$ & 6.3 & 2.4 \\
& $400 \mathrm{ng} / \mathrm{mL}$ & $434.2 \pm 14.70$ & 8.5 & 3.4 \\
\hline & $800 \mathrm{ng} / \mathrm{mL}$ & $886.0 \pm 28.48$ & 10.8 & 3.2 \\
\hline
\end{tabular}

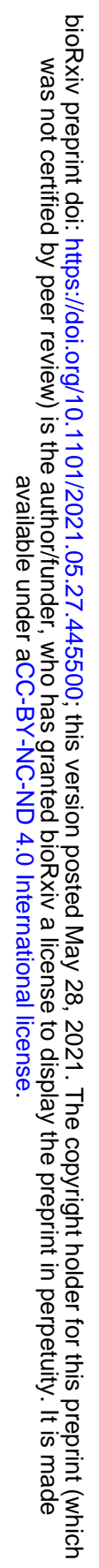


bioRxiv preprint doi: https://doi.org/10.1101/2021.05.27.445500; this version posted May 28, 2021. The copyright holder for this preprint (which

was not certified by peer review) is the author/funder, who has granted bioRxiv a license to display the preprint in perpetuity. It is made available under aCC-BY-NC-ND 4.0 International license.

\section{Figures}

Figure 1 shows the recovery of TIZ in mouse plasma, human plasma, 50\% FBS and 10\% FBS ( \pm SD).

Figure 2 shows example standard curves produced in mouse and human plasma. Also shown is the $R^{2}$ of the regression.

Figure 3 shows representative chromatograms of (A) extracted blank mouse plasma, (B) the extracted LLOQ in mouse plasma, (C) extracted blank human plasma and (D) the extracted LLOQ in human plasma. 


\section{Figure 1}

Mouse Plasma

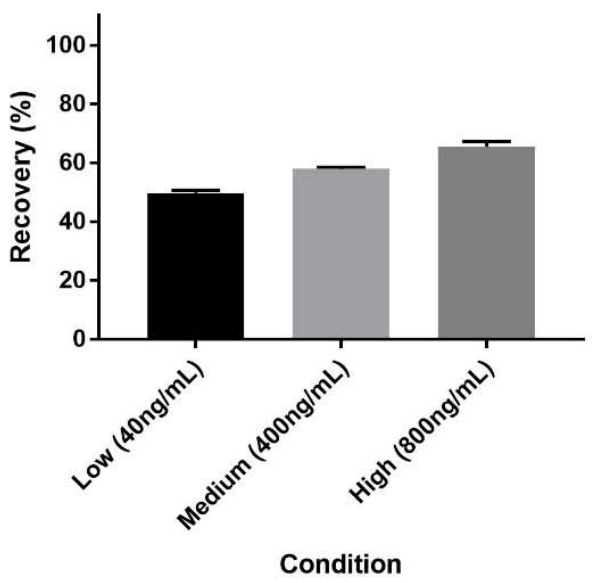

$50 \%$ FBS

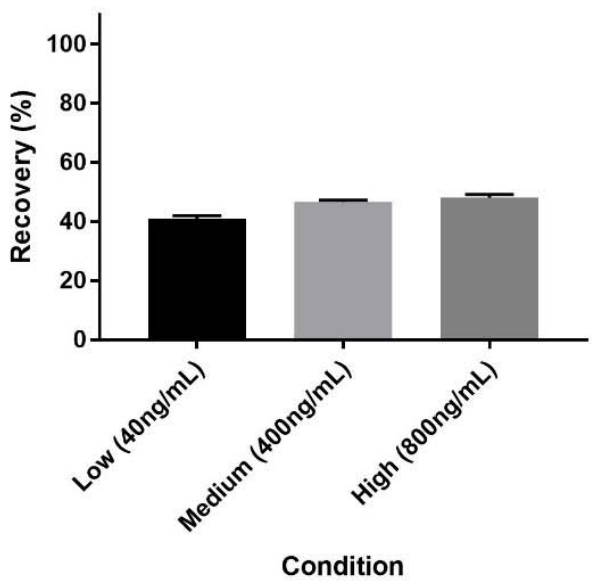

Human Plasma

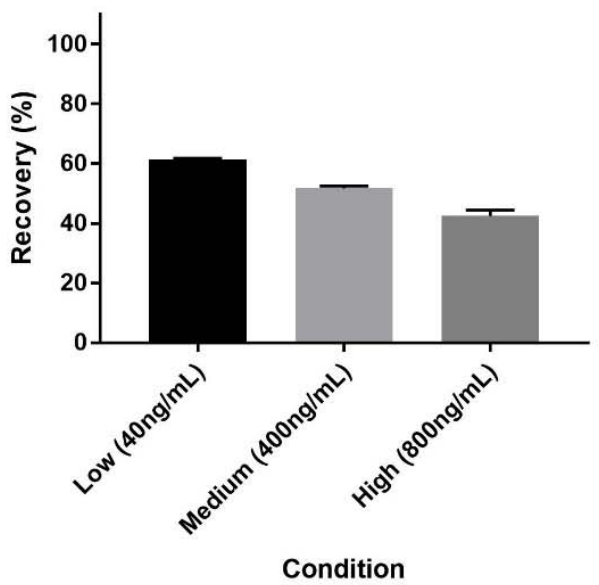

$10 \%$ FBS

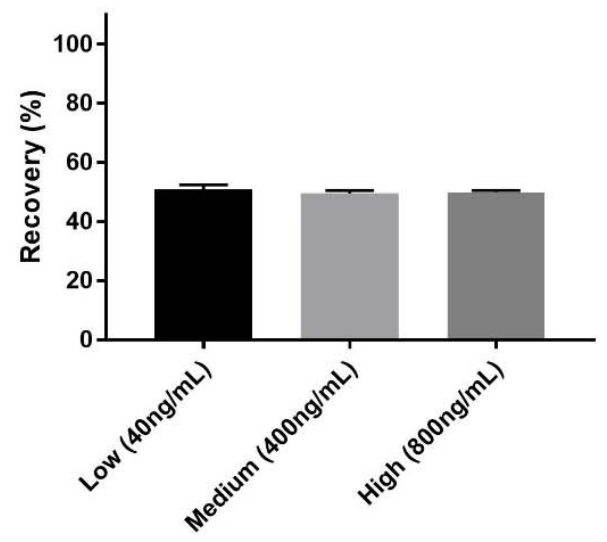

Condition 


\section{Figure 2}

Mouse Plasma

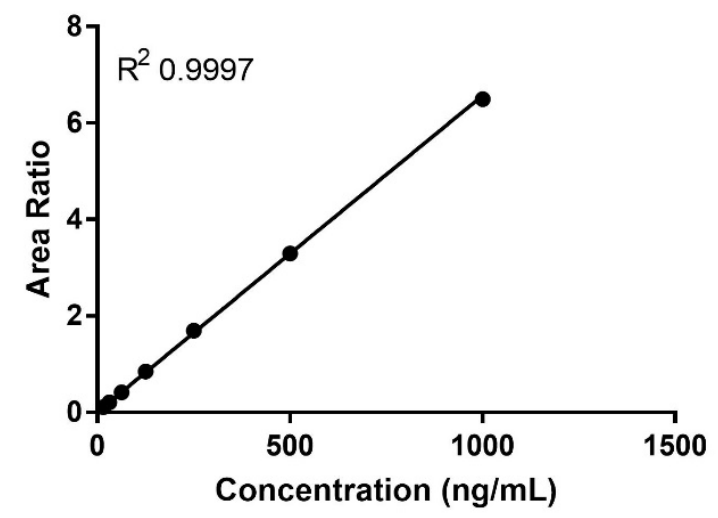

Human Plasma

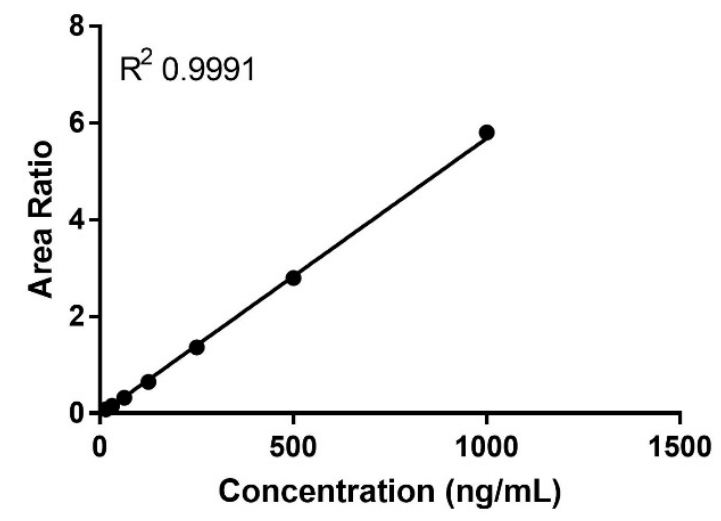


bioRxiv preprint doi: https://doi.org/10.1101/2021.05.27.445500; this version posted May 28, 2021. The copyright holder for this preprint (which

was not certified by peer review) is the author/funder, who has granted bioRxiv a license to display the preprint in perpetuity. It is made available under aCC-BY-NC-ND 4.0 International license.

\section{Figure 3}
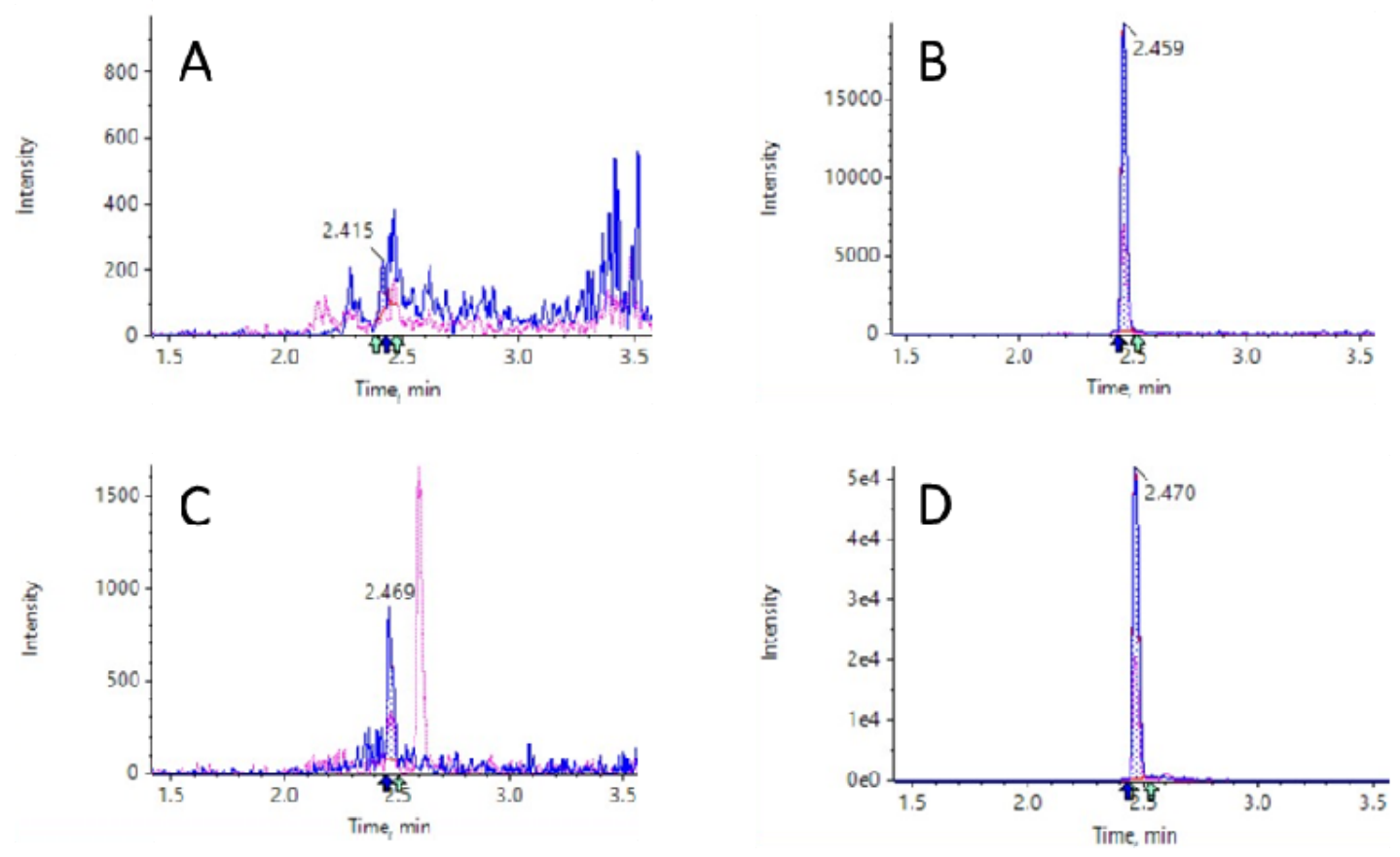